\title{
Operational Performance of the Selective Cutting of Trees With Chainsaw
}

\author{
Fidel Cándano Acosta ${ }^{1}$, David Christian de Oliveira ${ }^{1}$, Cleide Arruda ${ }^{2}$, \\ Marcos Leandro Garcia ${ }^{3}$, Rafael Rodolfo de Melo $^{4}$ \\ ${ }^{1}$ Universidade Federal de Mato Grosso - UFMT, Sinop/MT, Brasil \\ ${ }^{2}$ ONF Brasil, Cotriguaçú/MT, Brasil \\ ${ }^{3}$ Universidade do Estado de Mato Grosso - UNEMAT, Alta Floresta/MT, Brasil \\ ${ }^{4}$ Universidade Federal Rural do Semi-Árido - UFERSA, Mossoró/RN, Brasil
}

\begin{abstract}
The objective was to obtain a statistical model to estimate the operational performance of cutting trees with a chainsaw in the natural tropical forest north of Mato Grosso state. One-hundred-and-fifty-one operational cycles of selective logging for commercial purposes were registered. In each cycle, the effective time for cutting, the diameter of the trees, commercial height, the number of logs per tree, and the distance between trees was determined. A step-by-step regression analysis was performed to obtain the coefficients of the models and statistical parameters. The result of the analysis concluded that the most accurate model to estimate the operational performance is the one that transforms the diameter variable at breast height (DBH) squared and also includes the variables number of logs per tree and distance between logged trees.
\end{abstract}

Keywords: forest management, forestry operations. 


\section{INTRODUCTION}

The Amazon rainforest is characterized by a diversity of species, frequently encompassing more than 20 commercial species inventoried for logging through management plans. Also, the ecosystem extends through nine countries of South America and occupies approximately $55 \%$ of the Brazilian territory. According to the Brazilian Forest Service (SFB, 2016) all forest companies in the Legal Amazon consumed more than 14.2 million cubic meters of wood in logs in 2012; in 2016, the amount was 12.4 million of cubic meters. The state of Mato Grosso is responsible for more than $20.0 \%$ of this production.

Due to the complexity of the existing forest structure in the northern region of the state, it is necessary to apply selective polycyclic silvicultural management on mature trees with DBH equal or greater than $50 \mathrm{~cm}$, with rotation cycles of 25 to 35 years, considering a percentage of tree seedlings and trees for future logging, besides not cutting and avoiding damage to trees classified as forbidden to log, according to CONAMA (Brasil, 2009) and SEMA (Mato Grosso, 2009, 2014) resolutions.

According to Holmes et al. (2002), and FAO (2004), tropical forest exploitation is a dangerous, expensive operation with high environmental impact on the forest ecosystem. With an adequate system of forest exploitation, the cost and level of damage to the forest can decrease from $40 \%$ to between 6 and $15 \%$. Although technological advances have been observed in the machines used in the different logging operations, especially in the harvesting of planted forests, chainsaws continue to be widely used for logging in the tropical forest. Its use is justified by the complexity of the production process and the ease of use in selective cutting by applying techniques to control the direction of the fall of trees and avoid negative impacts on remaining trees.

Operational performance includes several indicators essential for the planning of forest harvesting operations, such as operational cycle time, productive capacity, among others. There are previous studies on chainsaw logging performance presented by Holmes et al. (2002), Cándano Acosta et al. (2004), Wang et al. (2004), Ghaffariyan \& Shobani (2007), Behjou et al. (2009), Chad Bolding et al. (2009), Borz \& Duță (2012), Pereira et al. (2012), Popovici (2013), and Leite et al. (2014). Specifically, in the natural forest of the Amazon region, the works presented by Winkler (1997), Minetti et al. (2000), and Batista (2008), developed in the state of Amazonas, stand out where the characteristics of trees to be logged differ compared to those in the state of Mato Grosso.

On the other hand, it is necessary to have statistical models that can estimate indicators that characterize the operational performance of the logging for different conditions of a natural forest that allows the managers of exploitation to predict the productive capacity to aid the planning of the use of timber. The authors cited above have conducted research without providing models that allow the estimation of technical indicators from variables that are easy to measure and provide accurate data.

The development of statistical models to estimate the production of chainsaw logging in natural forests has been approached by Hendrison (1990) in Suriname. The model relates the logging time according to the diameter at breast height and the density of the wood of the trees logged. In this sense, the research presented by Behjou et al. (2009) in broadleaf forests in northern Iran also stands out. The model relates the logging time as a function of the variables diameter at breast height and mean distance between cutting trees.

Other variables can influence the operational performance of logging with chainsaws, such as the natural inclination of the trees and the relationship with the desired direction of the cut, as well as the shape of the trunk of the trees that entails using different cutting techniques. These variables can change their proportion within the same logging area and the can limit the effect on the results. Also, the method or procedure used in the organization of the cutting operations can modify the operational performance. These independent variables have not been included by other researchers in the models of time estimation for logging, probably because they lead to a more detailed inventory that makes the production process more expensive and shows the result in the accuracy of the estimate.

Considering the above, the objective of this work is to evaluate the operation of selective logging using a chainsaw in tropical natural forest areas in the state of Mato Grosso state, collecting information that allows obtaining a statistical model with the necessary 
variables to estimate the operational performance with precision and ease. It also enables producers to have a tool to assist in the planning of the chainsaw logging operation.

\section{METHODS AND MATERIALS}

\subsection{Location of the study area}

The study was carried out in the property Nossa Senhora Aparecida, in the municipality of Cotriguaçú, northwestern region of the state of Mato Grosso, $920 \mathrm{~km}$ from the state's capital Cuiabá, located between latitudes $09^{\circ} 42^{\prime}$ and $09^{\circ} 45^{\prime}$ South and longitudes $58^{\circ} 53^{\prime}$ and $58^{\circ} 59^{\prime}$ West (Figure 1).

\subsection{General characterization of the area}

The property has a total extension of 414.17 hectares destined for forest management. Of this total area, 60.42 hectares are classified as Areas of Permanent Preservation (APP) and 353.75 hectares are authorized for logging for commercial purposes.

The climate corresponds to the tropical zone, with a pluviometric regime of two seasons: the rainy season, from October to April, and a less rainy season, from May to September. According to KÖPPEN, the region has an AM climate - characterized by a large amount of rainfall, over 2,000 $\mathrm{mm}$ annually. The relative humidity of the air is $80 \%$ and the thermal amplitude is small. Average temperatures range from 22 to $28^{\circ} \mathrm{C}$.

The soil in the municipality where the property is located is predominantly red-yellow podzolic soil with topography between flat and undulated. The altitude above the mean sea level is 260 meters and the vegetation of the area is classified as low altitude tropical forest with a great diversity ranging from 60 to 80 species per hectare and the number of individuals with $\mathrm{DBH}$ greater than $10 \mathrm{~cm}$ is about 600 .

\subsection{Work system and team characteristics}

The work team consisted of a chainsaw operator and an assistant. The operator had the role of cutting the trees, as well as observing the direction of fall, verifying if the trees had cavities, clearing the vegetation next to the tree to be logged and executing chainsaw maintenance operations.

The assistant was responsible for carrying the fuel, lubricant, chains, and reserve saber besides to locating the trees selected to be cut according to the inventory, supply the chainsaw and clear the trunk of the tree for the cut and the escape route. The workers evaluated had more than two years of experience in the operation.

The polycyclic system of selective logging of mature trees with $\mathrm{DBH}$ equal or greater than $50 \mathrm{~cm}$ is used, with maximum cut intensity at $30 \mathrm{~m}^{3} / \mathrm{ha}$ and a logging interval of 25 to 35 years. It is mandatory

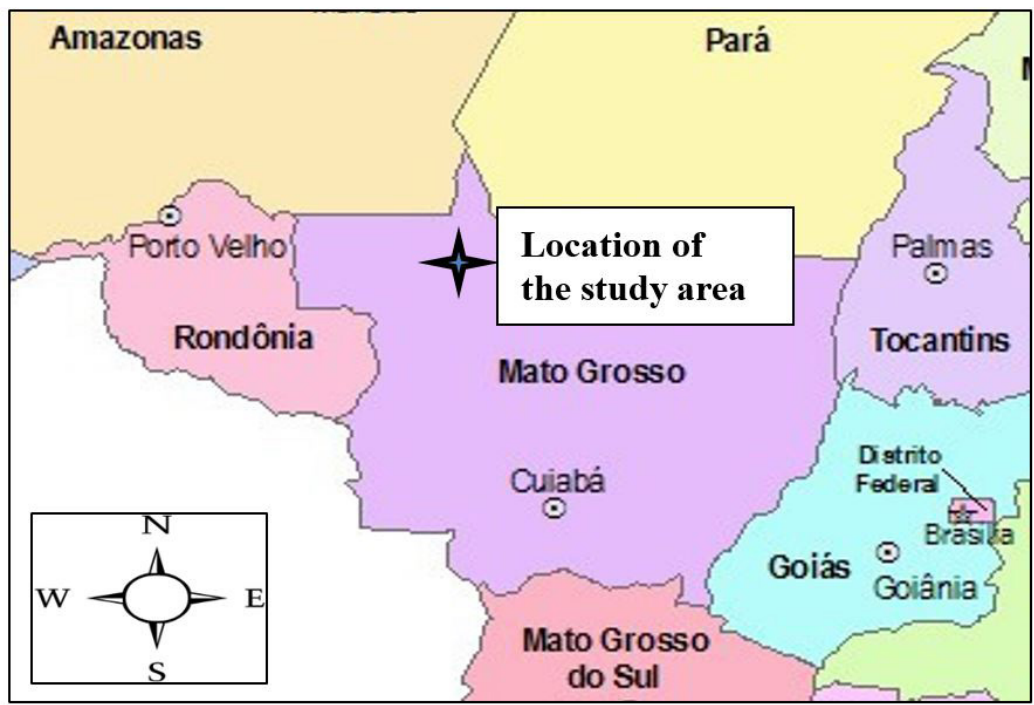

Figure 1. Location of the study area. 
to leave $10 \%$ of trees of this category as seed carriers, considering trees with a DBH smaller than $50 \mathrm{~cm}$ for future logging. Also, there are some species whose logging is forbidden by law and rare species, which are those with a frequency of less than 3 to 5 trees per 100 hectares, according to CONAMA (Brasil, 2009) and SEMA (Mato Grosso, 2009, 2014), respectively.

A map with a scale of 1:2000 is drawn up for the planning and execution of logging operations and a copy is given each day to the logging team, where the geographic location of the trees selected for cutting is represented. Other categories of trees are indicated to reduce damage during logging.

The technique used for logging is part of the application of Reduced Impact Logging (RIL) in broadleaf natural forests in the tropical region and it includes the location of trees according to geographic coordinates from the $100 \%$ inventory, which allows the logging team to establish a previous route on the map that guides the quick location of the next tree in the field. Once the tree is located, its plate number is checked, the cavity test is performed, the cutting decision is made, the area next to the tree is cleaned and the superficial part of the cortex where the cut is made is removed. Simultaneously, the operator determines the direction of fall of the tree, the assistant takes the nameplate, the operator performs the directional cut, and performs the felling cut, cutting and blunting the trees. Immediately, the identification plate is placed on the trunk of the cut tree and the number of the tree and the geographic location is written at the top of each log to guarantee the chain of custody and assist the logging team.

\subsection{Technical characteristics of the chainsaw}

- STIHL: model MS 660;

- Weight: $13 \mathrm{~kg}$ with fuel and $7.3 \mathrm{~kg}$ without the logging set;

- Cylinder capacity: $91.6 \mathrm{~cm}^{3}$ and $5.2 \mathrm{~kW}(7.1 \mathrm{CV})$ capacity;

- Fueling capacity: $0.825 \mathrm{~L}$ gasoline and $0.300 \mathrm{~L}$ lubricant.

The work team also had two sabers of different sizes, one smaller than $63.0 \mathrm{~cm}$ and one greater than $75.0 \mathrm{~cm}$ long.

\subsection{Data collection and characteristics of trees}

The field data collection was carried out in June and July 2014, accompanying the work team from the start of the camp to the end of the work shift, timing all activities performed. Data was collected from Monday to Friday, totaling ten full shifts. All information was recorded in a field card. Two digital timers were used to record the time of each element of the operational cycle that corresponds to the cutting of a tree, one stopwatch was zeroed at the end of each element of the cycle and of each tree cut, while the other stopwatch registered time on a continuous basis, following recommendations of Magagnotti et al. (2013). DBH data, commercial height, and distance between trees were measured in the logging area.

At the end of the data collection, we were able to put together a summary that lists the identification of each species, frequency, and presence or absence of tabular roots.

Fifty percent of the species registered had tabular roots on their trunks, although $63.57 \%$ of all trees logged only 6 species had the characteristics of a cylindrical trunk.

A characterization of the variables of the trees logged with their mean and extreme values was also carried out, which helps to explain the results.

\subsection{Elements of the operational cycle}

The operational work cycle includes all the activities performed for tree-logging within the exploitation area, not considering the time between the camp and the workplace and lunchtime (Figure 2).

\subsubsection{Time for locating trees}

Comprises the time needed for displacement and location between consecutive trees to be logged.

\subsubsection{Time for preparing the cut}

Time used to clear the vegetation that hinders to cut with the chainsaw, removing the bark where there is presence of termites, dirt and other things that damage the chainsaw chain. This also includes determining the direction of tree felling.

\subsubsection{Felling time}

Time needed to make the directional cut, which basically comprises a slant cut and a horizontal cut to one-third of the diameter of the tree approximately 

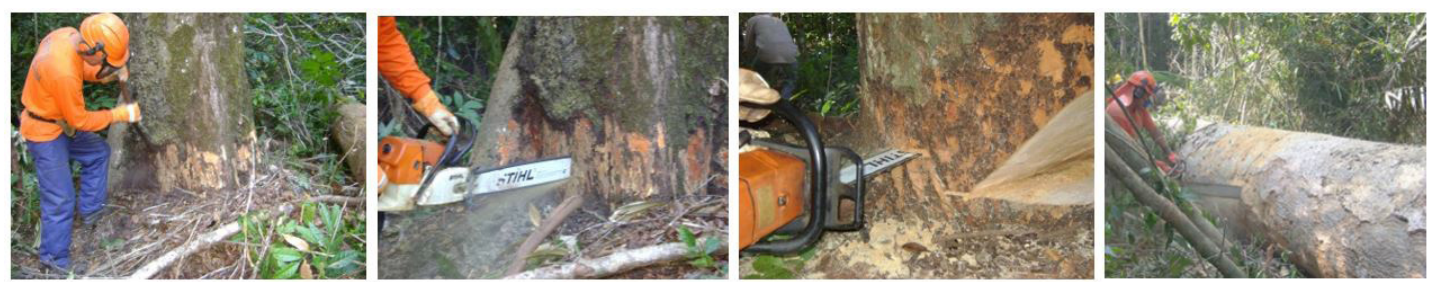

Figure 2. Operations of the logging cycle.

and the time of collapse of the tree. The time needed to perform the test to detect cavities in trees with split branches and presence of termites was also considered.

\subsubsection{Cutting time}

Time needed for the operator to move from the base of the tree to the cutting location, clearing the vegetation that impedes the operation with the chainsaw, measuring the appropriate length and the execution of the cuts needed.

\subsubsection{Interruption time}

Time in which the aforementioned cycle operations are not performed; this includes mechanical interruptions, personal interruptions, and operational interruptions.

\subsection{Information processing and analysis}

\subsubsection{Estimate of the number of operational cycles}

Through a pilot study, the minimum number of operational cycles for the tree logging using a chainsaw was estimated according to the methodology proposed by Barnes (1968). An acceptable sampling error of $10 \%$ and $95 \%$ probability was adopted (Equation 1 ).

$\mathrm{n} \geq \frac{t^{2 *} C V^{2}}{E^{2}}$

where: $\mathrm{n}=$ Minimum number of operational cycles needed; $\mathrm{t}=$ Student's $\mathrm{t}$ distribution, at the $\mathrm{y}(\mathrm{n}-1)$ level of probability; CV = Variation coefficient (\%); $\mathrm{E}=$ Acceptable error (\%).

\subsubsection{Finding a regression model to estimate the effective time of the operational cycle}

A correlation analysis was performed to determine which variables have the greatest influence on the effective time of the operational cycle. From this analysis, it was possible to verify the independent variables that had more relation with the total effective time, considering the dependent variable. To obtain the statistical model, we performed a step-by-step regression analysis and the coefficient of determination was adjusted through the results of the statistical parameters, ( $\left.R^{2} a j.\right),(S y x \%)$ Typical error of estimation, (Fcal.) Value of F calculated, the best model was selected. The statistical program SPSS 14 was used.

\subsubsection{Calculation of the operational performance of tree felling with a chainsaw}

Using the information on the volume of each tree obtained through Equation 2 and the time of the work cycle, the operational performance was calculated.

$R h=\frac{\mathrm{V} * 60}{\mathrm{Tc}}$

where: $\mathrm{Rh}=$ Operational performance, $\left(\mathrm{m}^{3} / \mathrm{he}\right) ; \mathrm{V}=$ Volume of the trees, $\left(\mathrm{m}^{3}\right) ; \mathrm{Tc}=$ Time of the cycle, $(\mathrm{min})$.

To estimate the volume of each tree logged, the following Equation 3 was used:

$V=0.785 * D B H^{2} * H c * f$

where: $\mathrm{V}=$ Volume of the trees, $\left(\mathrm{m}^{3}\right) ; \mathrm{DBH}=$ Diameter at breast height, $(\mathrm{m}) ; \mathrm{Hc}=$ Commercial height, $(\mathrm{m})$; $\mathrm{f}=$ Form factor (0.7). Indicated according to SEMA (Mato Grosso, 2009).

\section{RESULTS AND DISCUSSION}

\subsection{Statistical model to estimate the effective} time of the work cycle

Information on 151 work cycles or trees felled from 22 commercial species in the area of exploitation was recorded, Table 1. According to the calculation of the pilot study, 114 trees or work cycles would be necessary, which demonstrates the reliability of the results.

The correlation analysis between the studied variables confirmed the degree of association of the variables 
of the work cycle. The independent variables (DBH), distance between trees and number of logs were selected for the step-by-step regression analysis. Although the effective cycle time presented a high correlation with the height and the volume of the trees, they were not considered in the analysis because they were highly correlated variables $(\mathrm{DBH})$.

First, the analysis was performed using the $\mathrm{DBH}$ and the effective cycle time, the coefficient of determination was 0.69 and the typical error was $17.40 \%$. Observing the trend in the dispersion of the values in Figure 1, the transformation of the variable $(\mathrm{DBH})$ to the square was performed and a new model was obtained, with a larger adjustment with $R^{2}=0.77$ and an error of $16.13 \%$, Table 2 . In the third model, the variable distance between the trees and increase in the coefficient $\mathrm{R}^{2}=0.82$ and the error considerably reduced to $13.29 \%$ and the analysis was performed, including the independent variable number of logs per tree, the statistical parameters show superior behavior with $\mathrm{R}^{2}=0.85$ and the error decreased to $12.42 \%$.

Finally, by incorporating the variable distance between the cutting trees in the model, in addition to (DBH) and number of logs, a $\mathrm{R}^{2}=0.88$ was obtained and a decrease of the error to $9.73 \%$, that is, less than $10 \%$. The inclusion of the variables $(\mathrm{DBH})$ and distance

Table 1. List of species logged during the survey.

\begin{tabular}{|cccc|}
\hline Common name & Scientific name & Number of trees & Presence of tabular roots \\
\hline Amescla -aroeira & Protium heptaphyllum (Aubl.) & 18 & No \\
\hline Angelim-amargo & Vataireopsis speciosa Ducke & 3 & Yes \\
\hline Angelim-pedra & Hymenolobium sp & 8 & Yes \\
\hline Angelim-saia & Parkia sp & 6 & Yes \\
\hline Axixa & Sterculia chicha A. St.-Hil & 1 & Yes \\
\hline Cambará & Qualea sp & 2 & No \\
\hline Canelão & Ocotea velutina (Nees) Rohwer. & 5 & No \\
\hline Catuaba & Thyrsodium schomburkianum & 1 & No \\
\hline Cumaru-ferro & Dipteryx odorata Willd. & 4 & Yes \\
\hline Farinha-seca & Albizia hasslerii Chodat. & 1 & Yes \\
\hline Garapeira & Apuleia Ieiocarpa Vogel & 7 & Yes \\
\hline Goiabão & Pouteria pachycarpa Pires & 4 & No \\
\hline Guaritá & Astronium lecointei Ducke & 1 & Yes \\
\hline Ingá & Inga paraenses & 9 & No \\
\hline Ipê & Tabebuia chrysotricha & 10 & No \\
\hline Jatobá & Hymenaea courbaril & 8 & No \\
\hline Maçaranduba & Manilkara huberi (Ducke) & 24 & No \\
\hline Marinheiro & Guarea trichilioides $L$ & 27 & No \\
\hline Paraju & Manilkara longifólia & 1 & Yes \\
\hline Peroba-mica & Aspidosperma sp & 5 & No \\
\hline Rixinho & Peltogyne sp & 1 & Yes \\
\hline Tauari & Couratari oblongifolia & 5 & Yes \\
\hline
\end{tabular}

Table 2. Models and statistical parameters to estimate effective work time.

\begin{tabular}{|c|c|c|c|c|c|}
\hline \multirow{2}{*}{ No } & \multicolumn{2}{|l|}{ Models } & \multirow{2}{*}{$\begin{array}{c}\text { Coef. } \\
\left(\mathbf{R}^{2}\right)\end{array}$} & \multirow{2}{*}{$\begin{array}{l}\text { Syx } \\
(\%)\end{array}$} & \multirow{2}{*}{ Fcal. } \\
\hline & $\beta_{0}$ & $\beta_{3}$ & & & \\
\hline 1 & $5.3428+0.0015 * \mathrm{DBH}$ & & 0.69 & 17.40 & 204.5 \\
\hline 2 & $-4.2815+0.2461 *(\mathrm{DBH})^{2}$ & & 0.77 & 16.13 & 236.8 \\
\hline 3 & $-5.2369+0.2309 *(\mathrm{DBH})^{2}+0.0724 *(\mathrm{da})$ & & 0.82 & 13.29 & 221.7 \\
\hline 4 & $4.4465+0.0009 *(\mathrm{DBH})^{2}+2.2983 *(\mathrm{Nt})$ & & 0.85 & 12.42 & 267.2 \\
\hline 5 & $3.3109+0.0009 *(\mathrm{DBH})^{2}+1.9579 *(\mathrm{Nt})+0.0597 *(\mathrm{da})$ & & 0.88 & 9.73 & 261.8 \\
\hline
\end{tabular}

Where: $\beta_{0}, \beta_{1}, \beta_{2}$, and $\beta_{3}=$ regression coefficients; $\mathrm{R}^{2}=$ adjusted coefficient of determination; Syx $\%=$ typical error of estimation; $\mathrm{Fcal} .=$ Value of $\mathrm{F}$ in the analysis of variance; $\mathrm{DBH}=$ breast height diameter; $\mathrm{da}=$ distance between trees; $\mathrm{Nt}=$ number of logs per tree 
between trees agrees with the results presented by Wang et al. (2004) in the cutting of hardwoods with chainsaws in western Virginia-United States of America.

Behjou et al. (2009) published very similar results confirming the two variables $(\mathrm{DBH})$ and distance between trees to estimate the logging time of hardwood trees in Iran, with a $\mathrm{R}^{2}=0.84$, which can be considered a very close adjustment as obtained in this work of $\mathrm{R}^{2}=0.82$ for these two variables (Figure 3 ).

The statistical parameters show a result that characterizes the logging operation in selection forests where the variability of diameter is broad, where the resistance to logging has great variation depending on each species. The conditions of each tree for its location and preparation are also different, which expresses coefficients of determination of less than $90 \%$ and errors close to $10 \%$. The $\mathrm{F}$ value in all cases was significant.

Although the residue distribution graph was not presented, the analysis of homogeneity of the residues was performed and it was observed that the distribution of the variance behaved constant for all classes of diameters evaluated. Considering the above, model 5 was selected, with three independent variables to estimate the time of the effective tree cutting cycle.

As shown in Figure 4, there is a tendency to increase the time of the logging cycle as a function of diameter and number of logs per tree. The time of tree removal has a direct relation with the diameter of these trees, and the time of chopping increases with the increase of the diameter of the trees and with the number of logs that depends on the commercial height the trees and the characteristics of the skidder tractors. For this reason, it is very important that the model contain the independent variables tree diameter and number of logs.

Interruptions in the work cycle represent $24.72 \%$ of the total operational cycle time. Mechanical interruptions represent $16.62 \%, 5.28 \%$ interruptions are for personal needs and $2.82 \%$ are for operational interruptions. Most of the interruptions occur by mechanical operations, highlighting the time dedicated to sharpening the chain of the chainsaw, the fuel and lubricant supply, and the time to adjust the cutting mechanism, saber-chain. In the exploitation area, trees of the species Manilkara huberi (Masaranduba) predominate, since the characteristics of the wood tend to quickly damage the edge of the chain of the chainsaw.

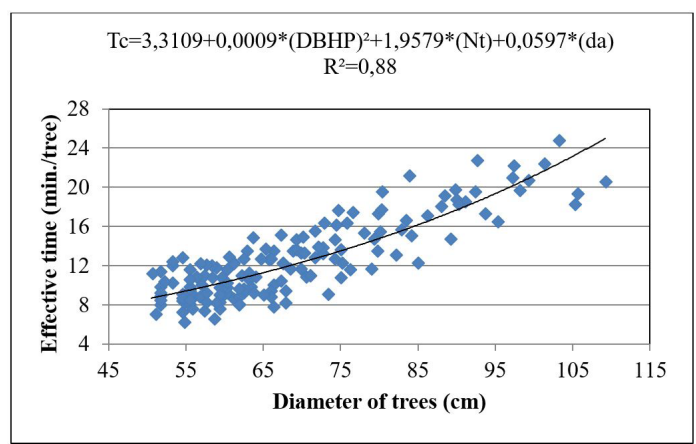

Figure 3. Effective cycle time depending on the diameter of trees.

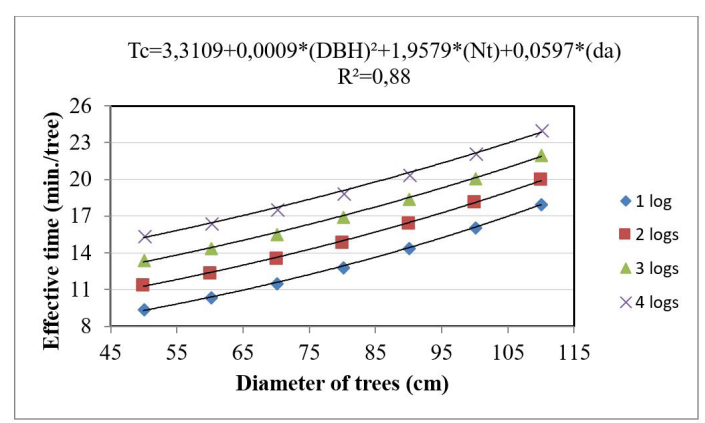

Figure 4. Effective time depending on the diameter and the number of logs.

The information shown in Table 3 allows calculating the operational performance and this information is a reference to compare the results found by other authors. The productive capacity for the effective time was of $19.60 \mathrm{~m}^{3} /$ he and for the total time of the cycle, including interruptions, it was $14.76 \mathrm{~m}^{3} / \mathrm{he}$. As the interruption time does not occur in all cut cycles and does not depend directly on the independent variables evaluated, there is a preference for the model to estimate the effective time of the operational cycle and to calculate the average time for the interruption time that is added to the effective time to obtain the total cycle time.

In this research, the average height of the trees was $13.96 \mathrm{~m}$, Table 3, while Winkler (1997) reports an average height of $16.78 \mathrm{~m}$ in the state of Amazonas for the same diameter of the trees presented in this work. These differences in the average height of the trees can alter the volume and simultaneously the operational performance. 
Table 3. Results of the variables that characterize the trees logged.

\begin{tabular}{lccc}
\hline Variables & Average & Minimum & Maximum \\
\hline $\begin{array}{l}\text { Distance } \\
\text { between } \\
\text { trees logged } \\
(\mathrm{m})\end{array}$ & 33.14 & 5.00 & 70.61 \\
$\begin{array}{l}\text { Number of } \\
\text { trees logged } \\
\text { per hectare }\end{array}$ & 5.15 & 3.00 & 9.00 \\
$\begin{array}{l}\text { Diameter of } \\
\text { trees }(\mathrm{cm})\end{array}$ & 68.76 & 50.96 & 109.23 \\
$\begin{array}{l}\text { Commercial } \\
\text { height }(\mathrm{m})\end{array}$ & 13.92 & 8.00 & 24.45 \\
$\begin{array}{l}\text { Number of } \\
\text { logs per tree }\end{array}$ & 1.58 & 1.00 & 4.00 \\
$\begin{array}{l}\text { Volume with } \\
\text { bark per tree } \\
\left(\mathrm{m}^{3}\right)\end{array}$ & 4.13 & 1.24 & 12.42 \\
\hline
\end{tabular}

The time values of the sawing cycle found by Winkler (1997), Minetti et al. (2000), Behjou et al. (2009), Batista (2008) and Cándano Acosta et al. (2012) are within the values estimated and represented in Figure 3. Operational performance may differ significantly depending on the characteristics of the trees even with similar operational cycle times. This is confirmed by the results presented by Behjou at al. (2009) with an average productive capacity of $26.1 \mathrm{~m}^{3} / \mathrm{h}$ for an average diameter (DBH) of $87.62 \mathrm{~cm}$ for chain sawing in natural forests in Iran. While in this work, the average productive capacity was $19.6 \mathrm{~m}^{3} / \mathrm{h}$ and for an average diameter (DBH) of $68.76 \mathrm{~cm}$. A lower score of $12.04 \mathrm{~m}^{3} / \mathrm{h}$ and with a mean $\mathrm{DBH}$ of $56.0 \mathrm{~cm}$ was published by Minetti et al. (2000) in logging in the state of Para.

\section{CONCLUSIONS}

Upon analysis of the results, we can conclude:

- With the help of the selected model, it is possible to estimate the effective time of the sawing cycle with less than $10 \%$ error for any kind of diameter, number of logs and distance between trees, provided the values are within the range for which the model was obtained, facilitating the information for the planning of the operation;

- To estimate the productive capacity in logging with a chainsaw, the commercial height of the trees for each region should be considered. The variable (DBH) has a high correlation with the cutting time of the trees, but for the same values of (DBH), the commercial height of the trees may be very different for each locality, which directly affects production estimates.

\section{SUBMISSION STATUS}

Received: 30 mar., 2017

Accepted: 1 aug., 2017

\section{CORRESPONDENCE TO}

\section{Fidel Cándano Acosta}

Universidade Federal de Mato Grosso - UFMT, Av. Alexander Ferronato, 1200, Distrito Industrial, CEP 78557-267, Sinop, MT, Brasil e-mail: fcandano23@gmail.com

\section{REFERENCES}

Barnes RM. Motion and time study: design and measurement ok work. 6th ed. New York: John Willey \& Sons; 1968.799 p.

Batista HL. Estudo de tempo e rendimento da motosserra considerando fatores ergonômicos numa exploração florestal na Amazônia Central [dissertação]. Manaus: Instituto Nacional de Pesquisas da Amazônia; 2008.

Behjou K, Majnounian B, Dvořák J, Namiranian M, Saeed A, Feghhi J. Productivity and cost of manual felling with a chainsaw in Caspian forests. Journal of Forest Science 2009; 55(2): 96-100. http://dx.doi.org/10.17221/69/2008-JFS.

Borz SA, Duță I. New software for timber harvesting, logging and landing site processing cost estimation. Bulletin of the Transilvania University of Braşov 2012; 5(54): 25-30.

Brasil. Conselho Nacional do Meio Ambiente - CONAMA. Resolução $n^{\circ}$ 406, de 2 de fevereiro de 2009. Parâmetros técnicos na elaboração, apresentação, avaliação técnica e execução de Plano de Manejo Florestal Sustentável-PMFS, nas florestas nativas no bioma Amazônia. Diário Oficial da República Federativa do Brasil, Brasília, DF (2009 fev.); 1-4.

Cándano Acosta F, Cuevas A, Leite AM, Machado CC, Oliveira RJ. Evaluación de los efectos de la rotación en operadores de motosierras. Revista Árvore 2004; 28(3): 367 372. http://dx.doi.org/10.1590/S0100-67622004000300007.

Cándano Acosta F, Leite AMP, Martínez Cantón JL. Optimización de los costos del sistema de aprovechamiento de madera en bosques naturales de Pinus carbaea. Revista Ceres 2012; 18(1): 33-40. http://dx.doi.org/10.1590/S010477602012000100005 .

Chad Bolding MS, Kellogg LD, Davis CT. Productivity and costs of an integrated mechanical forest fuel reduction operation in southwest Oregon. Forest Products Journal 2009; 59(3): 35-46. 
Food and Agriculture Organization - FAO. Reduced impact logging in tropical forests: literature synthesis, analysis and prototype statistical framework. Rome: FAO; 2004. 287 p.

Ghaffariyan MR, Shobani H. Cost production study of motor-manually felling and processing of logs. Forest Science 2007; 3: 69-76.

Hendrison J. Damage-controlled logging in a managed tropical rain forest in suriname. The Netherlands: Wageningen Agricultural University; 1990. (Ecology and Management of Tropical Rain Forest in Suriname; no. 4).

Holmes TP, Blate GM, Zweede JC, Pereira R Jr, Barreto P, Boltz F et al. Financial and ecological indicators of reduced impact logging performance in the eastern Amazon. Forest Ecology and Management 2002; 163(1-3): 93-110. http:// dx.doi.org/10.1016/S0378-1127(01)00530-8.

Leite ES, Fernandes HC, Guedes IL, Amaral EJ. Análise técnica e de custos do corte florestal semimecanizado em povoamentos de eucalipto em diferentes espaçamentos. Revista Ceres 2014; 20(4): 637-643. http://dx.doi.org/10 $.1590 / 01047760201420041340$.

Magagnotti N, Kanzian C, Schulmeyer F, Spinelli R. A new guide for work studies in forestry. International Journal of Forest Engineering 2013; 24(3): 249-253. http://dx.doi. org/10.1080/14942119.2013.856613.

Mato Grosso. Secretaria de Estado do Meio Ambiente - SEMA. Decreto $n^{\circ}$ 1.862, de 24 de março de 2009. Procedimentos de elaboração, análise e acompanhamento dos Planos de Manejo Florestal Sustentável no Estado de Mato Grosso. Diário Oficial do Estado do Mato Grosso, Cuiabá, MT (2009 mar.).
Mato Grosso. Secretaria de Estado do Meio Ambiente SEMA. Instrução Normativa SEMA no 5 de 2 de julho de 2014. Estabelece roteiros específicos para Plano de Manejo Florestal Sustentável-PMFS Madeireiro. Diário Oficial do Estado do Mato Grosso, Cuiabá, MT (2014 jul.).

Minetti LJ, Oliveira RF Fo, Pinto LA, Souza AP, Fiedler NC. Análise técnica e econômica do corte florestal planejado de floresta tropical úmida de terra-firme na Amazônia ocidental. Revista Árvore 2000; 24(4): 429-435.

Pereira D, Fiedler NC, Guimarães P, Môra R, Ramos Bolzan HM, Barbosa Plaster O. Avaliação da qualidade do corte florestal com motosserra. Revista Ceres 2012; 18(2): 197-203.

Popovici R. Estimating chainsaw operating costs based on fuel, lubricants and spare parts. Bulletin of the Transilvania University of Braşov 2013; 6(1): 64-68.

Serviço Florestal Brasileiro - SFB. Sistema Nacional de Informações Florestais [online]. Brasília: SFB; 2016. [cited 2017 Mar 30]. Available from: http://www.florestal.gov. br/snif/recursos-florestais

Wang J, Long C, McNeel J, Baumgras J. Productivity and cost of manual felling and cable skidding in Central Appalachian hardwood forests. Forest Products Journal 2004; 54(12): 45-51.

Winkler N. Aprovechamiento forestal compatible con el medio ambiente: ensayo sobre la aplicación del Código Modelo de la FAO en la Amazona Brasileña. Rome: FAO; 1997. 84 p. (Estudio Monográfico; no. 8). 